Revista Iberoamericana, Vol. LXXIV, Núm. 222, Enero-Marzo 2008, 1-

\title{
DE FRAY SERVANDO TERESA DE MIER A JUAN BAUTISTA MUÑOZ: LA DISPUTA GUADALUPANA EN VÍSPERAS DE LA INDEPENDENCIA
}

\author{
POR \\ SANTA ARIAS \\ Florida State University
}

En el Manifiesto apologético (1820) fray Servando Teresa de Mier se lamenta de la persecución a raíz de su famoso sermón y añade detalles de acosamientos recientes que incluyen la confiscación de importantes documentos personales de su celda del Castillo San Juan de Ulúa. ${ }^{1}$ La pérdida de su ejemplar de la Historia de la Revolución de la Nueva España (1813) y de sus seis cartas dirigidas al intelectual valenciano Juan Bautista Muñoz (1745-1799), las que describe como “unos siete cuadernos que compondrán unos cuarenta pliegos" (60), lo motivan a describir los abusos que ha sufrido de parte de las autoridades eclesiásticas. ${ }^{2}$ En una anotación suplica que se le entreguen estos documentos y advierte que "[d]e lo contrario, tribunales hay en México y España donde reclamarlos” (195). El tono de urgencia de sus reclamos apunta a la importancia que el remitente ya le depositaba a estas cartas que deben ser leídas como “cartas abiertas” destinadas al debate público. Entonces, ¿cómo encajan estas cartas dentro del corpus servandino y la cultura literaria de la Ilustración? ¿Por qué le escribe a Muñoz póstumamente? ¿Cuál es su verdadera intención? En cuanto a los argumentos antiaparicionistas, ¿en qué contribuyen al polémico debate guadalupano?

Para contestar a estas preguntas vemos cómo el sujeto enunciador se inscribe, una vez más, en el debate aparicionista, esta vez desde una perspectiva trasatlántica, al entablar una correspondencia ficticia con el célebre intelectual Juan Bautista Muñoz, quien ya había muerto en 1799. Mi aportación se fija en el valor de la exégesis y el dictamen crítico servandino al vigorizar el debate sobre la ausencia de un testimonio verificable de las milagrosas apariciones, discusión que ha continuado hasta el siglo veintiuno y que es evidente en recientes contribuciones de historiadores mexicanistas como Miguel León Portilla, James Lockhart y David Brading. Partiendo de los cuidadosos estudios de Christopher Domínguez Michael y Edmundo O’Gorman, quienes se han fijado en la

\footnotetext{
${ }^{1}$ Christopher Domínguez Michael, quien ha publicado la biografía más completa de Mier, señala que el Manifiesto apologético excede a las Memorias al ser una nueva "versión exagerada, ampulosa y violentísima” de las mismas.

${ }^{2}$ Muñoz fue nombrado cosmógrafo oficial de Indias durante el reinado de Carlos III, miembro de la Real Academia de la Historia y ha sido más conocido por su ardua labor como fundador del Archivo General de Indias. Véase el trabajo de Nicolás Bas Martín El cosmógrafo e historiador Juan Bautista Muñoz (1745-1799).
} 
importancia de las “Cartas a Juan Bautista Muñoz”, me concentro en el locus enunciativo, ese contexto de la escritura que ilumina otros textos; además, en la importancia que le prestan el remitente y el supuesto destinatario a la escritura para entender la construcción histórica, política y cultural de las apariciones.

\section{LA PREFERENCIA POR LAS CARTAS}

La cultura epistolar hispánica de la Ilustración ocupó un espacio público y político de vasta extensión y complejidad. Dado el establecimiento de la imprenta, el discurso epistolar se convirtió en instrumento público al servicio de intereses sociopolíticos dentro y fuera de las colonias. Son varios los temas que tenemos que tratar al acercarnos a estos textos: el primero es el de la ambigüedad genérica. Como ha señalado Thomas O. Beebee, el género epistolar se tiene que estudiar como un tejido discursivo que abraza diversos géneros a través del cual se ejerce y se negocia el poder. Al utilizar el concepto de genealogía de Foucault, Beebee se enfoca en el poder de la cultura epistolar con sus pugnas, resistencias, tensiones, apropiaciones y negociaciones. En el campo de la ficción el uso de cartas apropia el estatus y poder de las funciones establecidas dentro de otras prácticas discursivas (3-4). Importante, también, es el uso social, heterogéneo y fuerza política de la forma epistolar al presentar una forma fragmentada y plural como la encontramos en las enciclopedias y en los diálogos literarios (6). Como veremos, esta interpretación es apropiada dentro del contexto más amplio de la relación epistolar entre Mier y Muñoz, y la intención manifiesta en las cartas. Éstas no son personales, son cartas abiertas que sitúan el conflicto aparicionista entre narradores y, asimismo, son ensayos críticos en los que confluyen historia, relación y memoria para comentar y refutar otros textos y profundizar sobre la situación colonial novohispana.

Debemos considerar que dentro del contexto cultural peninsular, las instituciones culturales creadas bajo el auspicio de la Casa de Borbón, tales como las academias o las sociedades económicas y patrióticas, promovieron el avance de una cultura literaria pública (Glendinning 102). La elección de escribir memorias o “cartas abiertas” de intelectuales ilustrados de la segunda mitad del siglo xvıI refleja la intención de llevar las ideas a audiencias más selectas y tertulias dominadas por “la discusión apasionada” (103). La intención de toda carta abierta es uno de los problemas críticos subyacentes en la lectura de las mismas. Inspirados por el espíritu de la Ilustración, los intelectuales estaban muy conscientes de la escritura como instrumento político y de su poder impreso. Benedict Anderson en Imagined Communities acentúa la importancia del lenguaje, la imprenta y el mercado libresco en la formación del imaginario nacional y la efervescente cultura epistolar de la Ilustración participa de estos procesos. La correspondencia entre los ilustrados criollos, como artefactos culturales e intelectuales, queda transformada en textos públicos, filosóficos y críticos que además amenazaban el orden social y político. En el caso de los exiliados políticos procedentes de las colonias españolas, la publicación de sus cartas en las ciudades europeas y americanas era vehículo de promoción política y de justificación de la independencia de las colonias. Mucha de la correspondencia servandina, destinada al entorno público e impresa en revistas y periódicos, como sus 
notorias cartas publicadas en El Español mientras residía en Londres, ilumina y enmarca el proyecto nacional de los patriotas criollos. ${ }^{3}$ No obstante, si se estudia el cuerpo epistolar de Mier encontramos que se reiteran los mismos temas: las precarias condiciones que sufría en la prisión, la persecución y una apología personal que se remonta al famoso año de $1794 .{ }^{4}$

En las seis cartas a Muñoz, Mier se inserta dentro del repertorio de intelectuales mexicanos que contribuyen a la historiografía crítica guadalupana. Las cartas tienen que leerse como un solo texto genéricamente ambiguo que enlaza la autobiografía, la historia y el ensayo crítico. La ambigüedad de los textos no descansa únicamente en su forma, sino en la situación ficticia que construye el sujeto remitente al presentarse en un diálogo epistolar con el prominente intelectual valenciano. El intercambio epistolar es una estrategia del autor para proyectarse dentro del espacio espectacular del supuesto corresponsal. Esta estrategia influye en el proceso de recepción del texto que coloca al remitente dentro del espacio privilegiado de la intelectualidad europea. ${ }^{5}$

A diferencia de la memoria, sermones o historias, con las cartas a Muñoz, Mier apela profundamente a la conciencia del lector público. Estas son el medio para comentar y defender la Memoria sobre las apariciones y el culto de nuestra señora de Guadalupe (1817) de Juan Bautista Muñoz e, indirectamente, refutar la Defensa Guadalupana (1819) de Manuel Gómez Marín, quien reacciona a la tardía publicación de la Memoria de Muñoz. Aunque fray Servando data su correspondencia con el año de 1797 mientras se encuentra en Burgos, por la evidencia textual y contextual manifiesta en el Manifiesto apologético y en legajos del caso de Mier ante la Inquisición, es evidente que las cartas fueron escritas en 1819 durante su estancia en los calabozos de la Inquisición, cuando ya había muerto su destinatario Muñoz. ${ }^{6}$ Según Domínguez Michael, con las cartas fechadas en 1797 él está intentando “engañarse y (engañarnos) ... con una versión menos ingenua” que la que hubiera escrito en esa década final del siglo XviII (87). Las seis cartas se presentan

\footnotetext{
${ }^{3}$ De los textos publicados en El Español, el más comentado ha sido la primera "Carta de un americano” publicada en 1811, año que las Cortes españolas prohibieron la circulación de esta publicación por sus posturas anticatólicas y anticoloniales. En la primera carta, Mier justifica la emancipación y el nacimiento de la república en Caracas. La segunda carta, publicada un año después, estrechamente ligada a la publicación de la Historia de la revolución de Nueva España, se enfoca en la insurrección de Miguel Hidalgo y en los eventos en torno a la lucha de emancipación. En estos textos, fray Servando utiliza la modalidad epistolar para dirigirse al influyente Blanco White y presentar de la forma más persuasiva los argumentos que justifican su causa patriótica. La relación de Mier y Blanco White la detalla Brading en Los orígenes del nacionalismo mexicano (94101).

${ }^{4}$ Muchas de las cartas de Mier se encuentran en la Biblioteca Lilly de la Universidad de Indiana y en la Benson de la Universidad de Texas en Austin.

${ }^{5}$ Notemos que no hay ninguna referencia en los textos de Juan Bautista sobre Mier. Aunque no me sorprende que lo hubiera conocido, particularmente dentro del contexto de la presentación de su caso ante las Cortes españolas. Lo que tenemos son las referencias de Mier donde se jacta de la relación que inició con el cronista de Indias.

${ }^{6}$ Ya sabemos, por referencias en las Memorias, que durante el año de 1797 Muñoz es consultado por el fiscal del Consejo de Indias sobre el caso Mier y expresa una opinión a favor del criollo. Sobre el complejo dictamen del Consejo de Indias y la Real Academia de la Historia, véase Domínguez Michael (144-48).
} 
enmarcadas dentro del contexto de los meses de prisión en Burgos, circunstancias tan agravantes como las del momento enunciativo de 1819. Es obvio que la escritura también tiene la intención de justificar la libertad personal y, como señala al final de la quinta carta, subsanar su "honor y crédito" que como veremos más adelante quedaron manchados por Manuel Gómez Marín, Presbítero del Oratorio de San Felipe de Neri en México.

El debate a través del AtláNTico

Es obvio notar que para 1794 el tema de las apariciones de la Guadalupe y la incipiente devoción popular ocupaba un lugar prominente en la conciencia de los intelectuales en México y España. Esto queda demostrado por los eventos mismos que envuelven la disertación de Muñoz que fue pronunciada originalmente el 18 de abril de 1794 ante la Real Academia de la Historia y en la capital novohispana en el sermón de fray Servando el 12 de diciembre del mismo año. El discurso de Muñoz presentaba la versión oficial que protegía la política colonial ante la exorbitante literatura aparicionista, criolla y anticolonial procedente de la Nueva España. Según Jacques Lafeye, Muñoz era el intelectual más preparado para exponer la postura oficial de este cuerpo que protegía la ortodoxia historiográfica (375). También hay que recordar que el cronista estuvo investigando en los archivos españoles por varios años antes de escribir su Historia del Nuevo Mundo (1793) y que es, precisamente, dentro de ese espacio investigativo que el tema guadalupano toma urgencia. ${ }^{7}$

Muñoz, a diferencia de otros historiadores españoles, fue formado en Valencia entre un grupo de intelectuales (entre ellos Gregorio Mayans) que dentro de su patriotismo tendían al jansenismo (Cañizares-Esguerra 190-93). ${ }^{8}$ Para estos influyentes ilustrados, la devoción popular de imágenes sagradas eran actos que reflejaban la ignorancia y las creencias en supersticiones prevalecientes en España y en sus colonias americanas. Entre las leyendas que los reformistas jansenistas refutaban se encontraban aquellas fijadas en el siglo xvir como la misión del apóstol Santiago y la aparición de la virgen del Pilar. ${ }^{9}$ La ideología jansenista es un punto de contacto entre Mier y Muñoz, además del claro desprecio por el escolasticismo español del cual Muñoz encontraba alivio en los textos del Siglo de Oro. ${ }^{10}$

\footnotetext{
${ }^{7}$ Sobre las influencias intelectuales de Muñoz en el desarrollo de su patriotismo, véase de CañizaresEsguerra, How to Write the History of the New World (190-203).

${ }^{8}$ Junto a otros ilustrados de gran prominencia, Muñoz participó en los círculos académicos, como la famosa tertulia de la fonda de San Sebastián, espacio intelectual donde se difundían los principios neoclásicos y se comentaban los textos clásicos y del Siglo de Oro español. Formaban parte de este circuito: Moratín, López de Ayala, Cadalso, Iriarte, entre muchos otros. Véase el trabajo de José Miguel Caso González sobre este tema.

${ }^{9}$ Sobre el jansenismo hispánico, véase Antonio Mestre.

${ }^{10}$ En sus Memorias, Mier asume una postura antiescolástica al criticar a los dominicos españoles que habían abandonado el estudio de las humanidades (1: 235). Para él, estos religiosos no habían producido nada de valor en los últimos doscientos años. D. A. Brading ha señalado que la atracción de Mier por el jansenismo se manifestó al condenar la donación papal de 1493 basadas en textos falsos que se habían utilizado para justificar la monarquía papal y el derecho canónico (Mexican Phoenix 221).
} 
El historiador valenciano forma parte del movimiento ilustrado, cuyos miembros escribían para limpiar de culpa a la patria española de los males cometidos durante la conquista que recuerdan historiadores europeos como De Pauw, Buffon, Raynal y Robertson. ${ }^{11}$ Mientras, al otro lado del Atlántico, los intelectuales criollos reaccionaban ante estas historias críticas que devaluaban el espacio físico y humano del hemisferio americano. Como vemos, en la labor de Juan José de Eguiara y Eguren, Francisco Javier Clavijero y Francisco Javier Alegre, entre otros, encontramos la respuesta americanista de los humanistas criollos de una forma clara y provocadora al defender el pasado prehispánico, exaltar las contribuciones amerindias, mestizas y criollas; y refamiliarizar a la intelectualidad europea con la riqueza física, cultural y humana del continente. Tanto los patriotas españoles que contribuyeron al desarrollo cultural durante el reinado de Carlos III (r. 1759-1788), como los intelectuales criollos, tomaron la ofensiva ante el discurso americanista europeo que degradaba el capital cultural americano. La necesidad de defender las virtudes españolas y solidificar el proyecto patriótico persuaden a que la Real Academia de la Historia le solicite a Juan Bautista Muñoz que escriba su Historia del Nuevo Mundo, de la cual, dadas las innumerables polémicas que causó, solo logró publicar el primer volumen. El texto está basado en fuentes que se recogen para la colección personal de Muñoz y el Archivo General de Indias que personalmente establece en 1785.

Ignorada ha sido la importante conexión de la postura antiaparicionista de la Real Academia de la Historia con el proyecto de defensa nacional que igualmente guía la fundación del Archivo de Indias y la escritura de una nueva historia crítica sobre el Nuevo Mundo. No es coincidente que se le haya pedido a Muñoz que disertara también sobre las apariciones que inspiraron la insurgencia novohispana; él ya tenía acceso a los archivos. Al igual que una nueva historia de la conquista, una refutación a las publicaciones sobre las apariciones era apremiante. Intelectualmente, Mier y Muñoz representan una modernidad diferente que estaba enmarcada por una visión espiritual erasmista, influida por la ciencia, la razón y la estética neoclásica. Ambos, bajo la influencia ideológica del jansenismo dieciochesco con sus puntos de contacto con el humanismo cristiano del Siglo de Oro, rechazaron críticamente cualquier evento que no se basara en documentos originales. La Historia y la Memoria de Muñoz se construyen sobre esta base filosófica de búsqueda de la verdad a través de sus fuentes. De ahí que el punto central de la polémica aparicionista sea la falta de evidencia textual. Después de la publicación de la Historia del Nuevo Mundo, Juan Bautista Muñoz señala que él recibió del archivista de Simancas documentos relativos a las apariciones de la virgen de Guadalupe en México. Estos los analiza en su Memoria o "Discurso-crítico histórico".

Muñoz hace hincapié en la aportación de Lorenzo Boturini Benaducci sobre las apariciones y se refiere a los nuevos documentos: el fragmento extraviado de la Historia de las cosas de la Nueva España del franciscano Bernardino de Sahagún y la carta de 1575 del virrey Martín Enríquez dirigida a Felipe II sobre la fundación de la ermita de Nuestra Señora de Guadalupe. Según Muñoz, el fragmento extraviado de Sahagún, “el más docto

\footnotetext{
${ }^{11} \mathrm{El}$ estudio que mejor resume los argumentos y el debate que suscito la publicación de estas historias de América es el de Antonello Gerbi La disputa del Nuevo Mundo: Historia de una polémica 17501900.
} 
en las antigüedades e historia de la Nueva España”, y la carta del Virrey presentaban clara evidencia de que la historia de las apariciones fue una invención posterior a 1531. Para él, había que considerar el hecho de que Sahagún no mencionara las apariciones y que describiera una sospechosa devoción de los indígenas en Tepeyac. Sahagún residía en México justamente durante el periodo de las apariciones. Sobre la carta del Virrey Enríquez a Felipe II, Muñoz señala: "Por este documento parece que casi medio siglo después del tiempo en que se ponen las aspiraciones en cuestión, no se tenía noticia en el lugar mismo donde se suponen acaecidas, ni se hallaba otro origen de la fundación de un razonable templo con la advocación a la Virgen de Guadalupe [...]” (695). A estos documentos se sumaba el silencio de fray Juan de Zumárraga, quien supuestamente había sido testigo ocular del milagro.

Juan Bautista Muñoz no ataca al culto, sino el discurso aparicionista que carece de autoridad documental y, con esto, refuta todos los esfuerzos de los intelectuales criollos de verificación del mito. Las implicaciones políticas del discurso de Muñoz eran claras, al negar el culto desde España justificaba la conquista española con las autoridades de su Historia e invalidaba el milagro mariano. Mientras, en la Nueva España el milagro guadalupano, como navaja de doble filo, por un lado, fomentaba la cohesión nacional necesaria para la independencia que, como arguye el antropólogo Claudio Lomnitz, estaba inspirada en el expansionismo religioso (17) y, por el otro, entre los criollos, justificaba la monarquía católica española.

EL CONTEXTO DE LA ESCRITURA

Durante los años en prisión de 1818 a 1820, Mier tuvo pleno acceso a la biblioteca del Santo Oficio. Esto le facilitó la escritura de las conocidas Apología y la Relación de lo que le sucedió en Europa, que según Mier escribió "por no tener otra cosa que hacer” y las cartas a Juan Bautista Muñoz (Manifiesto 59). No obstante, como todo lo que dijo e hizo Mier, estos comentarios son parte del drama autorreferencial que construye por medio de la escritura y que disminuyen su rol como intelectual de la causa insurgente.

Como ha señalado Christopher Domínguez Michael, durante este periodo de aislamiento Mier tiene la oportunidad de ampliar sus conocimientos de asuntos coloniales tempranos, lo que explica la producción de los fundamentales textos autobiográficos y apologéticos sobre el tema guadalupano con una sólida base documental (“Servando” 33). Al hacerlo, Mier construye un complejo argumento que va más allá de sus escritos revolucionarios durante su estancia en Londres. Ahora, al escribir desde las mismas “entrañas del monstruo”, el Santo Oficio, coinciden la defensa personal, la agenda autonomista y el famoso debate sobre las apariciones de la Guadalupe.

Las cartas representan otra oportunidad de defender la perspectiva antiaparicionista, así como abogar por su defensa e intervenir en el debate inmediato que suscita la circulación del tratado de Muñoz sobre la Guadalupe en la Nueva España. La seriedad del asunto está aliviada por el típico humor servandino. Los elementos que contribuyen a la dimensión ensayística del texto son el tono expositivo, las anotaciones al texto, el epígrafe introductorio de San Agustín y el controversial argumento al que se le da continuidad de 
una carta a otra. Igualmente, vemos cómo se conjugan los preceptos horacianos de instruir y deleitar: se instruye con la confesión y revisión de la historia y se deleita con la sátira y las anécdotas. Esto explica el humor que domina en muchos de sus documentos destinados al entorno público. Curioso es observar que las cartas que fray Servando dirige a sus amigos, cuya intención no es una disertación política (y pública), no tienen el humor de las Memorias o del Manifiesto apologético, ${ }^{12}$ sino que, por lo contrario, domina el tono pesimista y trágico que acompañaron sus desventuras de casi tres décadas.

La Memoria sobre las apariciones y el culto de Nuestra Señora de Guadalupe de México de Muñoz fue publicada justamente en 1817 en el tomo V de las Memorias de la Real Academia de la Historia. La publicación de este tratado rápidamente motivó una intensa reacción de parte de los criollos católicos en México que se extendió a lo largo del siglo xix. En el ensayo “La fiesta de Guadalupe” (1884) de Ignacio Manuel Altamirano, éste describe la situación en México: "Un rayo que hubiese caído en medio de la clerecía de México, no hubiese causado más espanto que el que causó la tremenda disertación entre todos los eclesiásticos de la metrópoli del virreinato”. Además señala, “Al espanto sucedió la indignación, una indignación que estalló por todas partes en dicterios, en quejas, en amargas acusaciones” (1187).

En 1819 se imprime en México la Defensa guadalupana ... contra Juan Bautista Muñoz escrita por el religioso Manuel Gómez Marín. Casi de inmediato le siguió la Apología de la aparición de la virgen de Guadalupe en México (1820) cuyo autor fue el antiguo diputado a las Cortés de Cádiz, José Miguel Guridi y Alcocer. Aunque el tratado de Gómez Marín ha sido considerado el más débil, al ser una “mediocre refutación”, fue el más popular (Lafaye 403) y el texto que aludió a Mier y su famoso sermón que había alarmado a toda la jurisdicción eclesiástica en 1794. Según Gómez Marín, antes de Muñoz, Mier presentó un sermón de “ideas nuevas, pero exóticas e infundadas” y “las autoridades públicas estimaron este crimen sin indulgencia: se escribió, se habló, se predicó en contra, salieron órdenes y edictos del Illmo. Sr. Haro y Peralta, y aun no satisfechos con estas demostraciones, ni aun con la retracción del desgraciado predicador, se le castigó y se le desterró a la clausura estrechísima de Caldas. ¡Tanto así cuida Méjico, y con este respeto conserva intacta la tradición!” (33). A juzgar por Gómez Marín, la persecución de Mier por las autoridades virreinales era bien merecida y servía de ejemplo del cuidado y respeto que "conserva[ba] intacta la tradición” (33).

Manuel Gómez Marín, orgulloso de ser español, en cinco apartados defiende la postura aparicionista con argumentos que niegan la necesidad de un documento original, evidencia textual que subraya el carácter milagroso de la pintura. La introducción comienza: "El silencio de los autores contemporáneos a las apariciones guadalupanas, ha sido siempre el fantasma con que la crítica infundada ha querido desacreditar este portento; y es también la única arma y el resorte poderosos, que hace jugar D. Juan Bautista

\footnotetext{
${ }^{12}$ En la primera carta a Muñoz, Mier se disculpa sobre su uso del humor: "La bondad de VS. me concederá este desahogo, porque lo es grande hablar de su pleito con quien lo entiende; y puede ser que VS. se divierta también, porque mi genio es festivo y el asunto tragicómico, y yo por no morir de pena si pienso seriamente en el exceso de mis males, los tomo y presento siempre por el lado que prestan al ridículo” (“Cartas” 765).
} 
Muñoz en la ruidosa Disertación que escribió en el año de 94, negando la realidad de esta maravilla [...]” (1). Gómez Marín defiende su argumento teóricamente con los preceptos de Cicerón y del dominico Melchor Cano. Según estas autoridades lo importante es el testimonio oral que pasa de generación en generación y, la escritura sería lo que llamamos el suplemento: “en Legibus prohíbe Cicerón que todo se escriba, aun cuando sea perteneciente á las costumbres: asegurando que si la materia fuere sagrada, es mejor conservarla por la tradición de las familias, que no por las escrituras” (17). Es con Cicerón que él le contesta la pregunta a Muñoz ¿cómo no se halla un escrito contemporáneo? Sobre las tres autoridades de Muñoz (Zumárraga, Sahagún y el virrey Enríquez), Gómez Marín aclara que no se puede inferir que el silencio del Virrey significara que no existieran noticias en México de las apariciones. Enríquez le contestaba la cédula del rey, la cual no pedía noticias de las apariciones (52-3). Por otro lado, sobre Zumárraga "no se debe extrañar en manera alguna su silencio, ni culparlo de negligencia o descuido: porque un milagro obrado a su vista, y a la de otros varios, y publicado inmediatamente a toda una ciudad populosa, ¿qué mucho es, que no cuidase de una diligencia, que por aquel tiempo no era necesaria?” (50). En cuanto a Sahagún, objeta que es imposible tener una respuesta ya que el único ejemplar pertenece a la colección de Muñoz que se encuentra en España. Según el presbítero, Muñoz le niega a México la protección del cielo y a España la hiere "intentando obscurecerles un motivo tan poderoso de seguridad y confianza" (np). Para Gómez Marín las apariciones aseguraban la hegemonía de la monarquía católica y para Muñoz una amenaza al orden colonial y al poder español.

“A tAL HURACÁN, TAL RUIDO”

La debilidad de los argumentos y la falta de evidencia que presenta el tratado de Gómez Marín, motiva a Fray Servando Teresa de Mier a contestar inmediatamente con seis cartas que responden a los seis apartados que componen la Defensa guadalupana. Mier, en su Manifiesto apologético, al recapitular su experiencia, sus pleitos ante el gobierno virreinal y el limitado éxito que tuvo, hace una referencia directa que explica cómo las cartas a Muñoz responden a la Defensa guadalupana de Manuel Gómez Marín:

No hubiera hablado en este Manifiesto de tal asunto, que después de veinticinco años creía yo sepultado en el olvido, o mejor instruidos sobre él a mis compatriotas, si el Dr. Gómez Marín, del oratorio de S. Felipe de México, no se hubiese puesto a hablar de mí con las mismas equivocaciones de que está llena toda su disertación o más bien declamación contra el Dr. Dn. Juan Bautista Muñoz. En ella no dice que negué la tradición de Guadalupe; pero dice que las proposiciones de mi sermón eran exóticas e infundadas. (59)

En cuanto a las cartas, Mier señala que en ellas hallará el Dr. Gómez “respuesta sólida a cuanto amontona y exagera contra Muñoz [...] hallará demostrados y probados todos los desatinos del edicto de Haro; y en fin, que no habrá otro camino que el que yo tomé para 
evadir, si fuese posible, los argumentos contra la tradición” (60). ${ }^{13}$ De aquí que para entender el contexto de las cartas tengamos que leerlas junto a sus intertextos: la Memoria de Muñoz, la Defensa de Gómez Marín y el Manifiesto apologético de Mier que aclara el contexto de la producción de sus cartas.

La primera carta de Mier es un exordio que anticipa los temas a tratar en las posteriores, pero más importante, es una presentación de su “caso". Antes de abordar el tema aparicionista, en esta suerte de exordio y pre-texto, el eje temático es el remitente mismo. Sabemos que la epístola es uno de los vehículos discursivos más propios para revelar los aspectos más íntimos del ser, quejas, episodios personales y opiniones. Al igual que en la apología, el discurso cae en lo legal con una defensa de su persona y de las ideas que apoyaban las perspectivas "neoaztecas” y antiaparicionistas que alarmaron al alto rango clerical novohispano que incluían la peregrinación de Santo Tomás por México antes de la llegada de los españoles.

Mier comienza con una recapitulación de su experiencia personal a raíz del sermón y le pregunta a Muñoz: “¿cree V.S. que por tal sermón merecía yo perder enteramente honor, patria y libertad? Ah señor, una es la causa que suena y otra es la verdadera” (760). Además, al igual que en la Apología y en el Manifiesto, con la reconstrucción textual de su experiencia de marginado y acosado, se autorrepresenta como víctima de la situación colonial y de los abusos de poder de los oficiales eclesiásticos. Estas revelaciones mueven el debate guadalupano del espacio religioso al terreno de lo secular (la crítica de la condición colonial), causa que es pública y, asimismo, personal.

Un aspecto fundamental de la cultura epistolar de la Ilustración es su dimensión pública y privada que debe estudiarse a la luz de la práctica autobiográfica. Durante el siglo dieciocho, el discurso autobiográfico se distingue por su arraigo en lo público y lo comunitario, más que por la autoexaminación espiritual propia del barroco o el individualismo que caracteriza la autobiografía del romanticismo. Es evidente que durante este periodo, la narrativa en primera persona se desarrolla con una subjetividad dominante, influida por el contexto del lugar (lo geopolítico) y las aspiraciones al bienestar social. El discurso autobiográfico (encarcelamiento, persecución y exilio) sirve de preámbulo al análisis del origen de la leyenda guadalupana dentro del contexto político colonial y, más importante, ejemplo de la opresión del estado español representado en la figura del arzobispo de Haro. ${ }^{14}$

\footnotetext{
${ }^{13}$ Aunque está documentado que Mier conoció a Muñoz mientras estuvo en España, por la evidencia interna el carácter ficticio de las cartas está claro. La segunda nota a pie de página de la tercera carta es una extensa anotación, donde al especular sobre el paradero de la copia manuscrito de Sahagún que utilizó Muñoz, hace referencia a los documentos que dejó inéditos Muñoz.

${ }^{14}$ Hay que dejar en claro que el drama de la persecución de Mier en la Nueva España y en Europa se reitera en numerosas cartas, ensayos, en el Manifiesto apologético y en el "Discurso autobiográfico" leído al tomar su cargo de diputado en el Congreso Constituyente Mexicano en 1822. En este breve discurso, Mier hace un recuento de su experiencia desde 1794, cuando pronunció su sermón guadalupano, y ruega, más de una vez, que se le devuelvan sus libros, documentos e insignias doctorales que fueron confiscados por los oficiales de la Inquisición en San Juan de Ulúa. Véase Fray Servando: Biografía, discursos, cartas.
} 
Si en la primera carta se recurre al discurso autobiográfico para enmarcar el debate guadalupano con su experiencia, en la segunda y en la tercera se reconstruyen los argumentos intelectuales y críticos de la tradición guadalupana como parte de una defensa de las acciones del sujeto remitente. En las cartas cuarta y quinta, Mier analiza las fuentes escritas que establecen la tradición y refuta la dimensión milagrosa de la imagen mariana en la tilma de Juan Diego.

En la segunda carta queda demostrado que lo que verdaderamente une a estos dos intelectuales es el espíritu humanista y el odio hacia la opresión y la tiranía de la Ilustración. Tanto fray Servando como Juan Bautista Muñoz admiran a Bartolomé de las Casas. Citan profusamente al dominico como fuente histórica, ideológica y modelo de acción en cuanto a los principios de igualdad y derechos humanos, fundamentos de la cultura liberal de la Ilustración. ${ }^{15}$ Mier reconstruye la historia del maltrato de los indios y las quejas de los religiosos como las del obispo Bartolomé de las Casas, quien había llegado a Guatemala en 1532; el obispo de Tlaxcala Julián Garcés; y Juan de Zumárraga, quien había partido para Roma seis meses después de las apariciones. Mier no puede entender cómo no se mencionan las apariciones en los varios breves, edictos y cartas que tratan de "probar la capacidad de los indios en asuntos de la fe, con los milagros que ha obrado el cielo a su favor o con ellos” (770). La crítica lascasiana de la condición degradante de las comunidades indígenas y la lucha por sus derechos juega un papel esencial en la justificación de la invención guadalupana:

Para comenzar a extender mis pruebas de la inexistencia de la tradición antes de los autores impresos, permítame VS. retroceder hasta el año 1517, época desgraciada de la herejía de nuestros encomenderos, más verdadera que verosímil [...]. Nuestros conquistadores se hacían por eso un juego y una diversión no solo de despojar a los indios, de herrarlos por esclavos y consumirlos bajo la más bárbara servidumbre; sino aporrearlos, degollarlos, ahorcarlos y quemarlos sin escrúpulo alguno. (769)

Según Mier, la invención sirve "para confirmar la fe de los indios y cubrir con este milagro el mal de los cristianos” (772). Como evidencia apunta al silencio de de Las Casas: “¿Cabe en juicio humano que este santo obispo que durante su larga vida llenó el orbe de los gritos, historias, tratados, escritos, memoriales y representaciones hasta morir en la demanda de proteger a sus indios, nunca hiciese valer en su favor un milagro tal como el de Guadalupe, si hubiese sido verdadero? Primero creyera yo que había faltado tinta y papel” (773). La razón fundamental para dudar de las apariciones es "que no se debe admitir tradición alguna sin documento antiguo que lo apoye y pueda resistir a los argumentos” (767). Con este planteamiento glosa y refuerza las ideas de Muñoz. No niega la ocurrencia en milagros y apariciones, pero entiende que hay muchos testimonios falsos.

Tenemos que entender que la escritura, esa necesidad del documento original que se encuentra en los archivos para la investigación, se privilegia entre los ilustrados. Como

${ }^{15}$ Para Juan Bautista Muñoz en su Historia del Nuevo Mundo, los textos de Bartolomé de las Casas son fundamentales para entender la historia de la conquista y la colonización. Aunque el cronista crítica duramente la Brevísima relación, cita copiosamente fragmentos de la Historia de las Indias y de la Apologética. 
señala Henri-Jean Martín, este periodo marca el momento de triunfo del texto sobre la imagen, de la retórica tipográfica sobre la oral (330). Mier quiere probar que la tradición no existió hasta 1648 cuando “comenzó a nacer de autores impresos” que construyeron “una comedia, novela o autosacramental” (768). Según Mier, “éstos no tuvieron otro fundamento que el ms. Mexicano del indio D. Antonio Valeriano, natural de Azcapotzalco, escrito unos 80 años después de la época asignada a la aparición, y lleno de anacronismos, falsedades, contradicciones, errores mitológicos e idolátricos” (768). Mientras Mier cuestiona el carácter milagroso de la imagen en la tilma de Juan Diego ${ }^{16}$ y rechaza el testimonio oral, Gómez Marín -autor del texto a quien verdaderamente le responde Mier y todavía sumergido en el barroco-basa su evidencia en estos dos elementos que no tienen lugar en el esquema interpretativo de los ilustrados.

En las cartas que siguen, los textos de Francisco de Florencia, Luis Becerra y Tanco, Miguel Cabrera, se incluyen también las opiniones de intelectuales dieciochescos como José Ignacio Bartoloche, Mariano Fernández de Echevarría y Veyta, Francisco Javier Clavijero, Lorenzo Boturini y Juan José Eguiara y Eguren, pasan por el cedazo crítico de Mier. En las cartas cuarta y quinta, Mier analiza el llamado manuscrito original, el Nican Mopohua y diserta sobre el contexto religioso y político de la época que justifica que los indios “comenzaron a hacerse cargo de nuestra religión”. Para él, era interesante ver cómo en México fueron los mismos indígenas los primeros en representar las "farsas de la conquista” al referirse al teatro evangelizar en el cual participaron.

Fray Servando Teresa de Mier lee dentro de su campo cultural cuando analiza el Nican Mopohua (“Aquí se cuenta”) en su quinta carta que irónicamente llama “el final de la comedia”. ${ }^{17}$ Como señala Domínguez Michael, es el primero en afirmar que este importante texto es un auto sacramental destinado a identificar a Guadalupe con Tonantzin (Vida, 122). Después de describir la popularidad que tenían los autos sacramentales durante la conquista en ambos lados del Atlántico, señala: "quiero decir que no me falta sino probar que el famoso ms. de D. Valeriano, cuyos anacronismos, contradicciones, falsedades y errores dejo probados, es una comedia, novela o auto sacramental a estilo de su tiempo en que se propuso persuadir que la Virgen de Guadalupe es la misma que ellos adoraban" (823). ${ }^{18}$

El sujeto remitente se coloca como defensor que glosa y autoriza el texto de Muñoz con una revisión crítica de la historiografía intelectual guadalupana y un análisis del texto fundacional de la tradición, el Nican Mopohua, mejor conocido como la Historia de las apariciones de Nuestra Señora de Guadalupe..$^{19} \mathrm{Al}$ texto original del Nican Mopohua, cuya autoría ha sido objeto de innumerables debates desde la época colonial, Mier se lo atribuye a Antonio Valeriano, indígena de Azcapozalco, quien llegó a enseñar en el célebre colegio de Santa Cruz de Tlatelolco.

\footnotetext{
${ }^{16}$ Un estudio reciente que explica la imagen de la tilma es el de Jeanette Favrot Peterson "Creating the Virgin of Guadalupe: The Cloth, the Artist, and Sources in Sixteenth-Century New Spain".

${ }^{17}$ El texto completo del Nican Mopohua se encuentra disponible en línea. Véase Nican Mopohua. ${ }^{18}$ Valeriano, quien era latinista y nahuatlato, enseñaba en el Colegio de Santiago de Tlatelolco donde se presentaban muchas de las comedias y autos sacramentales.

${ }^{19}$ Este relato y diálogo fue luego insertado como la segunda parte del conocido Huei tlamahuiçoltica.
} 
Según Mier, el relato guadalupano tuvo que haberse inspirado en otras apariciones que narran los cronistas. Específicamente, compara la relación de Juan Diego con el relato de Torquemada de una aparición de la virgen a un indio de Azcapozalco. Sin explicar por qué motivo, Mier comenta cómo Valeriano sustituyó los elementos de tiempo, lugar y personajes de la conocida historia. Más importante, aún, era que "los recados y las respuestas del indio están tomadas de la Sagrada Escritura [...]. A mi ver, las palabras primeras de la Virgen: 'hijo mío, Juan Diego, a quien yo amo como a pequeñito y delicado’, son copias de las de Dios, filius meus parvulus et delicatus, Ephrain. Las demás están copiadas de las que dijo Dios a Moisés [...].” (825). Con esto ya Mier, claramente, revela la producción del Nican Mopohua como un relato cristiano destinado a las prácticas catequistas de los misioneros.

Las preguntas que resaltan sobre el origen e intención del relato de las apariciones, el destinatario y el carácter sincrético transparente en la imagen y en el Nican Mopohua, por primera vez quedan explicadas por Mier. Para explicar la necesidad de amparo espiritual, él apunta a las condiciones de la comunidad indígena deterioradas por la esclavitud, las epidemias y el desagüe de la ciudad. Para Mier, Valeriano fue un Moisés que tenía que apacentar las ovejas con "la madre del verdadero Dios y antigua madre de la gente del Anahuac” (826). Al comparar el relato bíblico y la leyenda guadalupana: “Nada falta: El plagio es evidente, y por consiguiente la ficción” (826). Mier subraya los puntos claves que explican el origen de la tradición y cómo Valeriano, al apelar a la conciencia amerindia para explicar la generosidad mariana, lo que logra es reafirmar la identidad cultural mestiza y cristiana con la identificación entre Guadalupe y Tonantzin.

CONCLUSIONES

A excepción de la labor editorial de Edmundo O’Gorman y de la reciente Vida de fray Servando Christopher Domínguez Michael, lamentablemente los esfuerzos interpretativos de la producción discursiva de este fraile revolucionario se han enfocado en las Memorias y, más recientemente, en la Historia de revolución de Nueva España (Londres, 1812) ${ }^{20}$ Poca atención se le ha prestado al resto de su producción como las Cartas a Juan Bautista Muñoz, el Manifiesto apologético (1820), la Memoria política instructiva (1821) y los cuantiosos discursos y textos que representen la contribución ideológica de Mier a la emancipación patriótica mexicana. Este cuerpo documental, además de ofrecer una sucinta relación de los argumentos políticos de Mier, a quien Brading llama el ideólogo más original de la independencia mexicana (Los orígenes, 60), nos ofrece un detallado análisis de la cultura material, política e intelectual de la Ilustración europea y de sus manifestaciones americanas.

Aquí hemos visto cómo las cartas de fray Servando Teresa Mier a Juan Bautista Muñoz son documentos fundamentales para entender la complejidad del debate religioso aparicionista. Según las cartas, la tradición guadalupana (fundada en la oralidad), los atributos estéticos y la preservación de la famosa imagen que cuelga en la Basílica

${ }^{20}$ José Eleuterio González compendió y publicó estos textos inicialmente bajo el título de Biografía del benemérito mexicano. 
mexicana, no son pruebas concretas del evento milagroso. Con la canonización de Juan Diego y las publicaciones recientes sobre el fenómeno guadalupano (como fenómeno que ha cruzado fronteras físicas, lingüísticas y culturales), vemos cómo los elementos del debate original continúan siendo los mismos. Las reflexiones tempranas de Mier, particularmente las que aparecen en las cartas a Muñoz, tienen que estudiarse en su contexto dialogado y que descansan en la importancia de la escritura para verificar los eventos. Para estos, la milagrosa imagen no puede servir de evidencia, solo los documentos originales inexistentes.

A pesar de las posturas ideológicas que tuvieron en común fray Servando y Juan Bautista Muñoz, hay que dejar en claro que el historiador de Indias era un intelectual orgánico que escribía para defender su nación de las diatribas de historiadores extranjeros. Con su postura antiaparicionista, en contra de toda devoción popular, sin fundamento científico, le negaba a México la base de la religiosidad popular que inspiraba la independencia. No obstante, fray Servando al representarse en diálogo con el cosmógrafo se colocaba públicamente en el centro del debate, al lado de una de las figuras más prominentes de la España de Carlos III. Él defiende, corrige y expande los argumentos de Muñoz, con sus lecturas de las crónicas eclesiásticas de la colonia temprana que le permiten su estancia en prisión. Más importante aún, defender a Muñoz dentro del contexto legal, en el lugar y en el momento en que lo hace, le da fuerza a su crítica del aparato eclesiástico y virreinal. Mier utiliza la emergencia de la devoción popular para darle vuelta al asunto, sin perder de vista el objetivo anticolonial. Al negar las apariciones, Mier desenmascara el ímpetu colonizador que utilizó el cristianismo y su catequismo indígena como instrumento ideológico. Si algo lograron las apariciones fue atraer pragmáticamente a los indígenas a la fe católica a través de la imagen mariana.

Lo personal y lo público inciden en las cartas a Juan Bautista Muñoz; son textos escritos mediatizados por la experiencia de un individuo privado de su libertad individual, lo que motiva una defensa y apología personal que sirve de ejemplo de la corrupción política y religiosa novohispana. Con los elementos autobiográficos, fray Servando se inscribe, una vez más, como personaje de la historia nacional e intelectual patriótica. Además, participa de la tradición crítica de reconstrucción de la historia del culto que se nutre de los discursos sobre la autenticidad y la refutación de las apariciones. A diferencia de las Memorias o la Historia de la revolución, el debate de la construcción del mito transforma las cartas de Mier en una historia de las relaciones de poder y de la fuerza simbólica de la continuidad de la religiosidad popular peninsular en la América hispana y mestiza.

BiBLIOGRAFÍA

Altamirano, Ignacio Manuel. "La fiesta de Guadalupe”. Testimonios históricos guadalupanos [1794]. Torre Villar y Navarro de Anda, eds. México: FCE, 1999. 1128-1210.

Anderson, Benedict. Imagined Communities. Londres: Verso, 1983.

Bas Martín, Nicolás. El cosmógrafo e historiador Juan Bautista Muñoz (1745-1799). Valencia: Universitad de Valencia, 2002. 
Brading, D. A. Mexican Phoenix. Our Lady of Guadalupe: Image and Tradition Across the Centuries. Cambridge: Cambridge UP, 2002.

The First America. The Spanish Monarchy Creole Patriots and the Liberal State [1991]. Cambridge: Cambridge UP, 1998.

Los orígenes del nacionalismo mexicano. México: SepSetentas, 1973.

Beebee, Thomas O. Epistolary Fiction in Europe: 1500-1850. Cambridge: Cambridge UP, 1999.

Cañizares-Esguerra, Jorge. How to Write the History of the New World: Histories, Epistemologies and Identities in the Eighteenth-Century Atlantic World. Stanford: Stanford UP, 2001.

Caso González, José Miguel. “Nicolás Fernández de Moratín”. Historia y crítica de la literatura española. Ilustración y neoclasicismo. José Miguel Caso González, ed. Madrid: Castalia, 1983. 192-205.

Domínguez Michael, Christopher. “Servando, el historiador”. Istor 5/17 (2004): 21-42. Disponible en http://www.istor.cide.edu/archivos/num_17/dossier2.pdf Vida de Fray Servando. México, DF: CONACULTA; INAH, 2004.

Fray Servando. Biografía, discursos, cartas. Monterrey: Gobierno del Estado de Nuevo León; Universidad Autónoma de Nuevo León, 1977.

Gerbi, Antonello. La disputa del Nuevo Mundo: historia de una polémica 1750-1900. México: FCE, 1955.

Glendinning, Nigel. Historia de la literatura española. El siglo XVIII. Vol 4. Francisco Rico, ed. Madrid: Ariel, 2000.

Gómez Marín, Manuel. Defensa guadalupana... contra Juan Bautista Muñoz. México: Imprenta de Don Alejandro Valdés, 1819.

González, José Eleuterio. Biografía del benemérito mexicano. Monterrey: Imprenta de la calle de dr. Mier, 1876.

Lafaye, Jacques. Quetzalcoatl y Guadalupe. 4a edición. México: FCE, 1995.

León Portilla, Miguel. Tonantzin Guadalupe. Pensamiento náhuatl y mensaje cristiano en el "Nican mopohua". México: El Colegio Nacional; FCE, 2000.

Martin, Henri-Jean. The History and Power of Writing. Lydia G. Cochrane, trad. Chicago: U Chicago P, 1988.

Mestre, Antonio. “La ilustración católica en España”. Libéralisme chrétien et catholicisme libéral en Espagne, France et Italie dans la première moitié du XIXe siècle. Georges Dufour, Marie Anne Rubat du Mérac, Georges Virlogeux, eds. Aix-en-Provence: U. de Provence, 1989. 3-20.

Mier, Servando Teresa de. Memorias. 2 vols. México: Porrúa, 1982.

Manifiesto apologético. Escritos inéditos. J.M. Miquel y Hugo Díaz Thomé, eds. México: Colegio de México, 1944.

“Cartas del Doctor fray Servando Teresa de Mier al Cronista Mayor de Indias Doctor Juan Bautista Muñoz ”. Testimonios históricos guadalupanos. Torre Villar y Navarro de Anda, eds. México: FCE, 1999. 757-861.

Muñoz, Juan Bautista. Historia del Nuevo Mundo [1778]. Valencia: Generalitat Valenciana, 1990. 
"Memoria sobre las apariciones y el culto de Nuestra Señora de Guadalupe de México”. Testimonios históricos guadalupanos [1794]. Torre Villar y Navarro de Anda, eds. México: FCE, 1999. 689-701.

Nican Mopohua: Here It Is Told (Nov. 27, 2006): www.weber.ucsd.edu/ dkjordan/ nahuatl/nican/NicanMopohua.html

O’Gorman, Edmundo. Destierro de sombras. Luz en el origen de la imagen y culto de Nuestra Señora de Guadalupe de Tepeyac. México: UNAM, 1991.

Pavel, Thomas. "Literary Genres as Norms and Good Habits". New Literary History 34/ 2 (2003): 201-10.

Peterson, Jeanette Favrot. "Creating the Virgin of Guadalupe: The Cloth, the Artist, and Sources in Sixteenth-Century New Spain”. The Americas 61/4 (2005): 571-610.

Reeser, Todd W y Steven D. Spalding, trads. "Reading Literature/Culture: A Translation of 'Reading as a Cultural Practice'”. Style 36/4 (2002): 659-76.

Sousa, Lisa, Stafford Poole y James Lockhart. The Story of Guadalupe: Luis Laso de la Vega's Huei Tlamahuicoltica of 1649. Stanford: Stanford UP, 1998.

Torre Villar, Ernesto de la y Ramiro Navarro de Anda. Testimonios históricos guadalupanos [1794]. México: FCE, 1999. 
